\begin{tabular}{|l|l|l||}
\hline \multicolumn{2}{|c|}{ PublisherInfo } \\
\hline \hline PublisherName & $:$ & BioMed Central \\
\hline \hline PublisherLocation & $:$ & London \\
\hline \hline PublisherImprintName & $:$ & BioMed Central \\
\hline \hline
\end{tabular}

\title{
Alien genes in bacteria
}

\begin{tabular}{|l|c|l||}
\hline \multicolumn{2}{|c|}{ ArticleInfo } \\
\hline \hline ArticleID & $:$ & 4825 \\
\hline \hline ArticleDOI & $:$ & $10.1186 /$ gb-spotlight-20030808-01 \\
\hline \hline ArticleCitationID & $:$ & spotlight-20030808-01 \\
\hline \hline ArticleSequenceNumber & $:$ & 177 \\
\hline \hline ArticleCategory & $:$ & Research news \\
\hline ArticleFirstPage & $:$ & 1 \\
\hline \hline ArticleLastPage & $:$ & 2 \\
\hline \hline & & RegistrationDate : 2003-8-8 \\
\hline ArticleHistory & $:$ & OnlineDate \\
\hline \hline ArticleCopyright & $:$ & BioMed Central Ltd2003-8-8 \\
\hline \hline ArticleGrants & $:$ & \\
\hline \hline ArticleContext & $:$ & 130594411 \\
\hline \hline
\end{tabular}




\section{Cathy Holding}

Email: cholding@hgmp.mrc.ac.uk

Evidence for lateral gene transfer (LGT) contradicted earlier theories that bacteria evolve clonally, with daughters only inheriting genetic material from mothers. LGT is extensive and has played a major role in microbial evolution, and indeed genes may be transferred from phylogenetically quite distantly related organisms, making the construction of a meaningful phylogenetic tree difficult. In the August 8 Science, Vincent Daubin and colleagues of the University of Arizona argue, however, that too much weight is given to LGT in the phylogenetic analysis of bacteria, and by using a more conservative approach than the usual "reciprocal best hit" method to detect orthologous genes, they found that those available for phylogenetic reconstruction are consistent with a single tree (Science 2003, 301:829-832).

Daubin et al. analyzed quartets of related sequenced genomes whose phylogenetic relationship is known based upon small subunit ribosomal RNA sequence. They inferred the number of genes gained and lost, and lateral transfers, using the more conservative method that included only those genes having a single significant match per genome. They tested which of three possible alignment trees - that supporting the ribosomal RNA data, that supporting LGT, and the third not supporting any phylogeny was most likely and found little evidence to support LGT in their analyses.

"This suggests that most cases of alternate topologies represent false-positives due to reconstruction artefacts rather than the accumulation of LGT events with time... LGT is an important driving force in prokaryotic evolution and adaptation, but it is not always the explanation for instances of phylogenetic conflict," conclude the authors.

\section{References}

1. Horizontal gene transfer in microbial genome evolution

2. Science, [http://www.sciencemag.org/]

3. University of Arizona Department of Biochemistry and Molecular Biophysics, [http://www.biochem.arizona.edu/] 